\title{
Reduction of sitting time has a positive effect on the decrease of insulin resistance in patients with non-alcoholic fatty liver disease
}

\author{
Anna Sabinicz ${ }^{1}$, Dominika Maciejewska ${ }^{1}$, Małgorzata Kaczorowska ${ }^{1}$, Karina Ryterska ${ }^{1}$, Dominika Jamioł-Milc ${ }^{1}$, \\ Joanna Wyszomirska-Raszeja르. Izabela Gutowska ${ }^{1}$, Ewa Stachowska ${ }^{1}$ \\ ${ }^{1}$ Department of Biochemistry and Human Nutrition, Pomeranian Medical University, Szczecin, Poland \\ 2Department of General, Transplant, and Liver Surgery, Medical University of Warsaw, Warsaw, Poland
}

Gastroenterology Rev 2016; 11 (4): 257-262

DOI: $10.5114 / p g .2016 .61355$

Key words: non-alcoholic fatty liver disease, International Physical Activity Questionnaire (IPAQ), physical activity, sitting time, diet.

\begin{abstract}
Address for correspondence: Prof. Ewa Stachowska PhD, Department of Biochemistry and Human Nutrition,
Pomeranian Medical University, 24 Broniewskiego St, 71-460 Szczecin, Poland, phone: +48 9144148 06, fax: +48 9144148 07, e-mail: ewast@sci.pum.szczecin.pl
\end{abstract}

\begin{abstract}
Introduction: Non-alcoholic fatty liver disease (NAFLD) affects a large part of the human population. One of the major environmental factors associated with the risk of NAFLD is the lack of physical activity.

Aim: To compare the level of physical activity and the insulin resistance in NAFLD patients.

Material and methods: Thirty patients with NAFLD underwent a six-month dietary intervention based on the principles of classical dietetics. Data about diet and physical activity was based on 72-hour nutrition diaries and International Physical Activity Questionnaire (IPAQ). Standard blood biochemical analyses were carried out before and after diet at the University Hospital Laboratory.

Results: The study showed that total physical activity and physical activity in leisure time are negatively correlated with insulin resistance (HOMA-IR) $(p<0.05)$. Insulin $(p<0.05)$, body weight $(p<0.05)$, and waist-hip ratio (WHR) $(p<0.05)$ were also negatively correlated with physical activity in free time. In addition, we noticed a positive correlation between sitting time and the risk of insulin resistance, in the case of HOMA-IR and insulin concentration $(p<0.05)$.

Conclusions: Dietary intervention and a physical activity plan are important factors in the treatment of non-alcoholic fatty liver disease. Taking regular exercise increases insulin sensitivity and prevents further development of the disease. It seems that diet and physical activity are not the only one risk factors of NAFLD. Our study reveals that the reduction of sitting time has a positive effect on the level of insulin and it reduces insulin resistance in patients with NAFLD.
\end{abstract}

\section{Introduction}

Non-alcoholic fatty liver disease (NAFLD) affects a large part of the human population. It is estimated that the incidence of the disease, depending on the country, is $10-24 \%$. When it comes to obese people, NAFLD will develop among $57.5-74 \%$ of cases in the population [1, 2]. The crucial factors in the development of NAFLD are: hyperinsulinaemia, insulin resistance, increased lipolysis of peripheral tissues, oxidative stress, and the accumulation of triglycerides (TG) in hepatocytes.

One of the major environmental factors associated with the risk of NAFLD is the lack of physical activity. It results in a positive energy balance. The balance is the main cause of obesity and it leads to insulin resistance
[3]. The cells lose their sensitivity to insulin, which is reflected in increased gluconeogenesis and hyperglycaemia. On the other hand, the insulin resistance may result in increased insulin secretion and hyperinsulinaemia. High levels of the hormone stimulate hepatic synthesis of fatty acids and leads to steatosis $[4,5]$. Insulin sensitivity can be achieved mainly through appropriate diet and physical activity.

Physical activity reduces insulin resistance, regardless of weight reduction. Population studies show that $43-87 \%$ of adult Europeans do physical activity, but it is irregular. Regularity of exercise is essential for the prevention of civilisation diseases. In the case of a preventative role, moderate physical activity should last 
at least 30 min or 10,000 steps per day. The same result can be achieved with intense exercise three times a week for $20 \min [6]$.

\section{Aim}

The aim of the study was to compare the level of physical activity and the insulin resistance in NAFLD patients.

\section{Material and methods}

\section{Patients}

Thirty patients with non-alcoholic fatty liver disease were enrolled in the study.

Liver steatosis was assessed by ultrasound (Acuson X300) according to the Hamaguchi score [7]. All patients had negative history of alcohol consumption (less than $20 \mathrm{~g}$ of pure alcohol/day). The study group underwent a 6-month dietary intervention based on the principles of classical dietetics. The diet was created using DIETETYK 6.0 software (Jumar, Poland). Data about diet and physical activity was based on 72-hour nutrition diaries and the international physical activity questionnaire (IPAQ). The study protocol was approved by the Ethics Committee of Pomeranian Medical University and conformed to the ethical guidelines of the 1975 Declaration of Helsinki.

\section{Study plan}

Study plan was presented in Figure 1.

\section{Diet}

The diet was matched to the individual calorie needs of each patient. Nutrition intervention helped to permit the reduction of body weight in overweight and obese people and allowed us to control and stabilise diabetes and dyslipidaemia. Protein intake was $1.0 \mathrm{~g} / \mathrm{kg}$ body weight/day. Most proteins came from dairy products and fish. Dietary fibre was at 25-30\%. Vitamin and mineral intake was provided by the appropriate amount of vegetables and fruit. Special attention was paid to the supply of vitamins, which plays a key role in the proper functioning of hepatic enzymes (vitamins A, K, $\mathrm{C}$, and B). Sodium intake was limited to $5 \mathrm{~g} /$ day. Energy from fat ranged from $20 \%$ to $35 \%$ of the total energy intake (E). Recommended dietary fats such as cream, milk, butter, and vegetable oils were easily digestible. The energy derived from carbohydrates ranged from $50 \%$ to $65 \%$ of $\mathrm{E}$.

\section{Diet control}

The patients were asked to take home and complete a 72-hour food diary (with 1 free day). The dietary records were validated by a nutritionist. The diet diary booklet contained menus, pages to record foods, and photographs of food that depicted portion choices for a common food item. The dietician reminded the patients to record the food brand and portion size. The amounts consumed were recorded in household units by volume or by measuring with a ruler.

\section{Anthropometric measurements}

During the study, anthropometric (anthropometric callipers, tape measure) and tissue bioimpedance measurements (Akern BIA) were performed. The analysis of resting metabolism rate was made using Fitmate Pro from the Cosmed system (Italy). Anthropometric parameters were analysed as follows: weight (medical

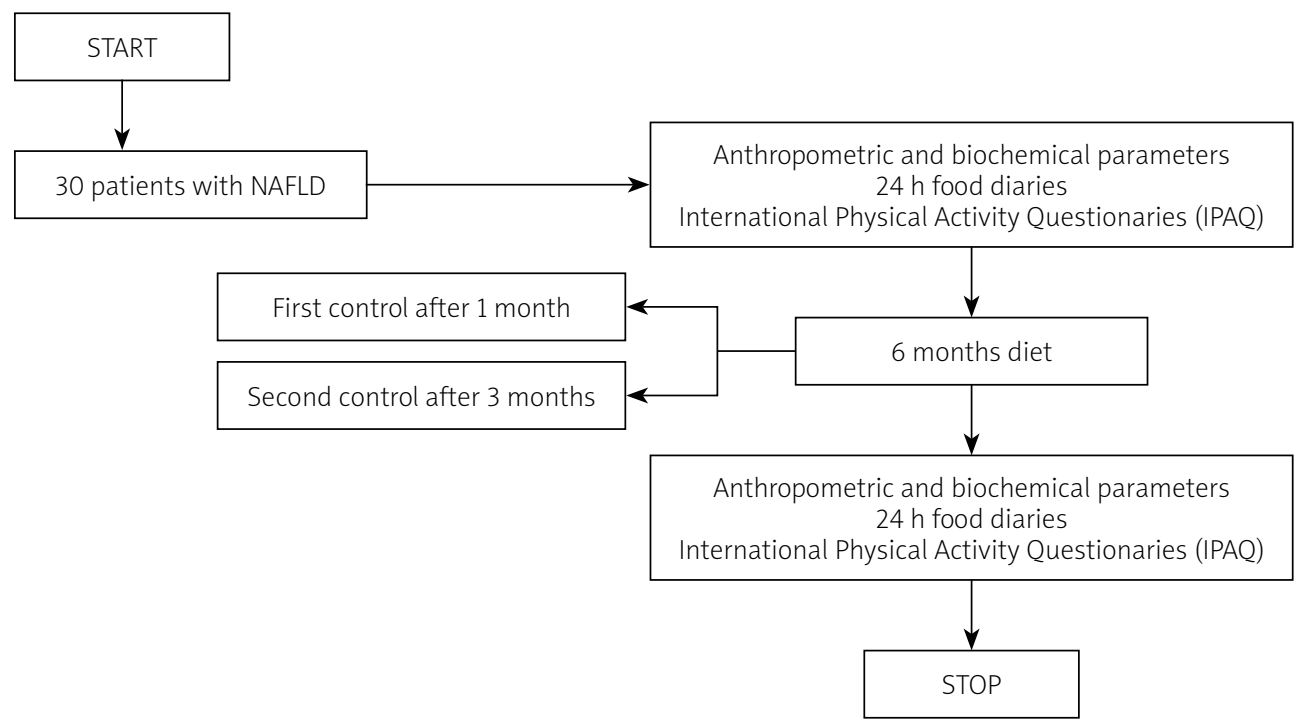

Figure 1. Study plan 
weight, Radwag WPT 100/200 OW), body height (medical weight, Radwag WPT model 100/200 OW), arm circumference, waist circumference, hip circumference (tape measure), and the amount of body fat (anthropometric compasses, bioimpedance device Akern BIA). Body mass index (BMI) was calculated according to the formula: $\mathrm{BMI}=$ body weight $[\mathrm{kg}] /$ height $\left[\mathrm{m}^{2}\right]$.

\section{Physical Activity Questionnaire}

The level of physical activity was assessed using the questionnaire technique with validated International Physical Activity Questionnaire (IPAQ) [8]. Physical exercise was estimated with MET units (min/week). The patients were classified into appropriate activity categories: below 600 MET for low, $600-1500$ or $600-3000$ MET for moderate, and higher than 1500 or 3000 MET (min/week) for high activity.

\section{Insulin and glucose content measurements}

Whole blood was collected into ethylenediaminetetraacetic acid (EDTA) tubes. The blood was immediately placed on ice or in a refrigerator until standard blood biochemical analyses were carried out at the University Hospital Laboratory.

\section{Statistical analysis}

Statistical analysis was performed using Statistica 7.1 software. As the distribution in most cases deviated from normal (Shapiro-Wilk test), non-parametric Mann-Whitney test was used for comparisons between groups, and $p<0.05$ was considered statistically significant. The data obtained in the study is shown by the mean and standard deviation. Spearman test was used to reveal the correlation between data.

\section{Results}

During the 6-month dietary intervention patients reported significant changes in anthropometric parameters. A reduction of the following parameters was noticed: BMI (from $30.84 \pm 4.33 \mathrm{~kg} / \mathrm{m}^{2}$ to $28.99 \pm 3.95 \mathrm{~kg} / \mathrm{m}^{2}$ ), fat mass (from $33.91 \pm 10.25 \mathrm{~kg}$ to $30.14 \pm 8.65 \mathrm{~kg}$ ), fat tissue (from $37.62 \pm 8.26$ to $35.15 \pm 8.18 \%$ ), lean body mass (from $55.58 \pm 10.48$ to $52.24 \pm 12.69 \mathrm{~kg}$ ), and body water content (from $41.28 \pm 7.12$ to $40.47 \pm 7.08 \%$ ). The results are presented in Table I.

The analysis of physical activity questionnaires showed significant changes in the level of intensity and type of physical activity performed by the patients. According to the study, physical activity at work was strongly limited in each of the analysed aspects: walking (from $1920.6 \pm 1379.71$ to $2114.18 \pm 1558.04$ ), moderate activity (from $2612.5 \pm 2147.87$ to 1158.46 \pm 1762.77 ), intense activity (from $2325.71 \pm 3432.04$ to $2160 \pm 3702.40$ ), and the total activity at work (from $4124.313 \pm 5436.01$ to $2187.8 \pm 3977.36$ ) (Table II).

A significant decrease in physical activity was also observed in the case of activity associated with movement: walking (from $1413.75 \pm 1387.01$ to 828.85 \pm 949.63 ), cycling (from $1110 \pm 946.78$ to 557.143 \pm 916.98 ), and total transport (from $118475 \pm 1599.16$ to $1300.10 \pm 958.85$ ) (Table III).

Table I. Anthropometric characteristics of the study group

\begin{tabular}{lcc} 
Anthropometric feature & $\begin{array}{c}\text { Before diet } \\
\text { Mean } \pm \text { SD }\end{array}$ & $\begin{array}{c}\text { After 6-month diet } \\
\text { Mean } \pm \text { SD }\end{array}$ \\
\hline WHR & $0.99 \pm 0.06$ & $0.94 \pm 0.06$ \\
\hline BMI $\left[\mathrm{kg} / \mathrm{m}^{2}\right]$ & $30.84 \pm 4.33$ & $28.99 \pm 3.95$ \\
\hline Fat mass $[\mathrm{kg}]$ & $33.91 \pm 10.25$ & $30.14 \pm 8.65$ \\
\hline Fat tissue $[\%]$ & $37.62 \pm 8.26$ & $35.15 \pm 8.18$ \\
\hline Lean body mass $[\mathrm{kg}]$ & $55.58 \pm 10.48$ & $52.24 \pm 12.69$ \\
\hline Water [\%] & $41.28 \pm 7.12$ & $<0.05$ \\
\hline
\end{tabular}

Table II. Physical activity at work

\begin{tabular}{lcc} 
Parameter & $\begin{array}{c}\text { Before diet } \\
\text { Mean } \pm \text { SD }\end{array}$ & $\begin{array}{c}\text { After 6-month diet } \\
\text { Mean } \pm \text { SD }\end{array}$ \\
\hline Walking [MET, min/week] & $1920.6 \pm 2114.18$ & $1379.71 \pm 1558.04$ \\
\hline Moderate physical activity [MET, min/week] & $2612.5 \pm 2147.87$ & $1158.46 \pm 1762.77$ \\
\hline Intense physical activity [MET, min/week] & $2325.71 \pm 3432.04$ & $2160 \pm 3702.40$ \\
\hline Total physical activity at work [MET, min/week] & $4124.313 \pm 5436.01$ & $2187.8 \pm 3977.36$
\end{tabular}


Table III. Physical activity during transport

\begin{tabular}{lccc} 
Parameter & $\begin{array}{c}\text { Before diet } \\
\text { Mean } \pm \text { SD }\end{array}$ & $\begin{array}{c}\text { After 6-month diet } \\
\text { Mean } \pm \text { SD }\end{array}$ & $P$-value \\
\hline Walking [MET, min/week] & $1413.75 \pm 1387.01$ & $828.85 \pm 949.63$ & $<0.05$ \\
\hline Cycling [MET, min/week] & $1110 \pm 946.78$ & $557.143 \pm 916.98$ & $<0.05$ \\
\hline Total transport [MET, min/week] & $1184.75 \pm 1599.16$ & $958.85 \pm 1300.10$ & $<0.05$
\end{tabular}

Table IV. Physical activity at home

\begin{tabular}{lccc} 
Parameter & $\begin{array}{c}\text { Before diet } \\
\text { Mean } \pm \text { SD }\end{array}$ & $\begin{array}{c}\text { After 6-month diet } \\
\text { Mean } \pm \text { SD }\end{array}$ & $P$-value \\
\hline Intense physical activity around home [MET, min/week] & $1891.61 \pm 2888.10$ & $1272.86 \pm 1366.33$ & $<0.05$ \\
\hline $\begin{array}{l}\text { Moderate physical activity around home } \\
\text { [MET, min/week] }\end{array}$ & $1278.75 \pm 1241.39$ & $871.11 \pm 1498.50$ & $<0.05$ \\
\hline Moderate physical activity at home [MET, min/week] & $671.67 \pm 840.85$ & $672.22 \pm 668.56$ & NS \\
\hline Total physical activity at home [MET, min/week] & $2169.25 \pm 3021.08$ & $1163.33 \pm 1594.41$ & $<0.05$
\end{tabular}

Table V. Physical activity in free time

\begin{tabular}{lccc} 
Parameter & $\begin{array}{c}\text { Before diet } \\
\text { Mean } \pm \text { SD }\end{array}$ & $\begin{array}{c}\text { After 6-month diet } \\
\text { Mean } \pm \text { SD }\end{array}$ & $P$-value \\
\hline Walking [MET, min/week] & $443.44 \pm 339.96$ & $891 \pm 991.04$ & $<0.05$ \\
\hline Moderate physical activity [MET, min/week] & $180 \pm 84.85$ & $244 \pm 210.57$ & $<0.05$ \\
\hline Intense physical activity [MET, min/week] & $1248 \pm 1204.79$ & $1736.67 \pm 3367.63$ & $<0.05$ \\
\hline Total physical activity in free time [MET, min/week] & $456.5 \pm 728.14$ & $1310.6 \pm 2258.26$ & $<0.05$
\end{tabular}

The analysis of the questionnaires showed a decrease in physical activity performed during housework: intensive activity around the house (from $1891.61 \pm 2888.10$ to $1272.86 \pm 1366.33$ ), moderate activity around the house (from $1278.75 \pm 1241.39$ to $1498.50 \pm 871.11$ ), and total physical activity associated with housework (from $2169.25 \pm 3021.08$ to $1163.33 \pm 1594.41$ ) (Table IV).

During leisure time patients spent significantly more time doing physical activity, especially in the case of: walking (from $443.44 \pm 339.96$ to $991.04 \pm 891$ ), moderate activity (from $180 \pm 244$ to $84.85 \pm 210.57$ ), intense activity (from $1248 \pm 1204.79$ to $1736.67 \pm 3367.63$ MET, $\mathrm{min} /$ week), and total activity in leisure time (from 456.5 \pm 728.14 to $1310.6 \pm 2258.26$ ) (Table V).
The analysis of total moderate physical activity showed that patients limited this type of activity (from $3025.92 \pm 3344.52$ to $1876.67 \pm 2242.65$ ). We also observed an almost two-fold increase in intense activity (from $750.67 \pm 1904.85$ to $1414.67 \pm 3109.86$ ). The resultant total physical activity associated with all types of activity was reduced (from $6010.13 \pm 5584.89$ to $5620.58 \pm 4855.29$ ) (Table VI).

During the project patients spent significantly less time in a sitting position. This reduction is related to the total time spent in a sitting position (from 2606.25 \pm 1337.89 to $1778.59 \pm 1393.21$ ), as well as the average time of sitting (from $372.321 \pm 191.13$ to 254.09 \pm 199.03 ) (Table VII).

Table VI. Total physical activity

\begin{tabular}{lcc} 
Parameter & $\begin{array}{c}\text { Before diet } \\
\text { Mean } \pm \text { SD }\end{array}$ & $\begin{array}{c}\text { After 6-month diet } \\
\text { Mean } \pm \text { SD }\end{array}$ \\
\hline Walking [MET, min/week] & $2233.55 \pm 2425.33$ & $2329.25 \pm 2237.58$ \\
\hline Moderate physical activity [MET, min/week] & $3025.92 \pm 3344.52$ & $1876.67 \pm 2242.65$ \\
\hline Intense physical activity [MET, min/week] & $750.67 \pm 1904.85$ & $1414.67 \pm 3109.86$ \\
\hline Total physical activity in free time [MET, min/week] & $6010.13 \pm 5584.89$ & $5620.58 \pm 4855.29$
\end{tabular}


Table VII. Sitting time

\begin{tabular}{lcc} 
Parameter & $\begin{array}{c}\text { Before diet } \\
\text { Mean } \pm \text { SD }\end{array}$ & $\begin{array}{c}\text { After 6-month diet } \\
\text { Mean } \pm \text { SD }\end{array}$ \\
\hline Total sitting time [min/week] & $2606.25 \pm 1337.89$ & $1778.59 \pm 1393.21$ \\
\hline Average total sitting time [min/day] & $372.321 \pm 191.13$ & $254.09 \pm 199.03$
\end{tabular}

Table VIII. Correlation between data

\begin{tabular}{lcc}
\hline Comparative data & Spearman's rank correlation coefficient (rho) & $P$-value \\
\hline Total activity in free time vs. WHR & -0.485342 & $<0.05$ \\
\hline Total activity in free time vs. BMI & -0.468239 & $<0.05$ \\
\hline Total activity in free time vs. insulin & -0.549815 & $<0.05$ \\
\hline Total activity in free time vs. HOMA-IR & -0.53828 & $<0.05$ \\
\hline Total activity vs. HOMA-IR & -0.442857 & $<0.05$ \\
\hline Sitting time vs. insulin & 0.524603 & $<0.05$ \\
\hline Sitting time vs. HOMA-IR & 0.50554 & $<0.05$
\end{tabular}

Spearman rank correlation test was made in order to show the correlation between the types of physical activity and insulin resistance parameters (HOMA-IR and insulin) $[9,10]$. Statistically significant results are shown in the following table (Table VIII).

\section{Discussion}

In our study, total physical activity was expressed as physical activity performed at work, in free time, during housework, and during transportation. We also measured the total time spent in a sitting position.

The project involved 30 patients with NAFLD. During a 6-moths dietary intervention and increased physical activity recommendation patients improved crucial anthropometric features: waist-hip ratio, BMI, and fat mass. During the study patients decreased the levels of several physical activities, such as: home activities, transport activity, and home activity. We suggest that the reason why patients spent less time on those activities may be correlated with different seasons of the year. The project lasted for 2 years and the patients were involved during different months. However, total physical activity in free time was significantly increased. This can be caused by higher awareness in the group of involved patients. We think that the main reasons that the anthropometric features decreased were proper diet, exercise in free time, and less time spent in a sitting position. Furthermore, we found a very interesting connection between activity and insulin sensitivity parameters among our patients.

Spearman's correlation showed that the total physical activity in leisure time is negatively correlated with basic markers of insulin resistance: HOMA-IR $(p<0.05)$ and insulin $(p<0.05)$. Patients who spent their free time more actively also experienced a decrease in body weight $(p<0.05)$ as well as WHR $(p<0.05)$. In addition, we noticed a negative correlation between total physical activity and HOMA-IR $(p<0.05)$. The results show that patients who spent more time on any type of physical activity decreased the risk of developing insulin resistance, which is the main cause of NFLD progression. The influence of physical activity on improving insulin resistance was previously described. The activation of GLUT 4 protein responsible for the transmembrane transport of glucose, insulin potency increase, and the improvement of glucose tolerance are all associated with the mechanism of muscle sensitivity to insulin. The improvement of glucose tolerance occurs after a week of training. This change appears regardless of body weight [11]. Bogdanski et al. showed that 50 min of exercise at the level of $70-75 \%$ of maximum heart rate (HRmax) performed for seven days increases insulin sensitivity and glucose tolerance by $35 \%$. Another study revealed that 30 min of daily exercise (70-75\% HRmax) helped reduce insulin concentration in $36 \%$ of patients [12]. Pilacinski et al. suggested a correlation between a lack of physical activity and type I diabetes. The researchers point out that exercise increases insulin sensitivity, which has beneficial effect on the patients [13].

During the 6-month dietary intervention patients with NAFLD showed positive correlation between time spent sitting and increased risk of insulin resistance. The differences in insulin concentration $(p<0.05)$ and 
HOMA-IR $(p<0.05)$ were directly proportional to the amount of the total and the average total sitting time.

Hallsworth et al. compared physical activity among patients suffering from NAFLD and healthy volunteers. The study showed that patients with NAFLD spent significantly more time in a sitting position. They were also more reluctant to perform intensive physical activity than the control group. The researchers point out that individuals are often unaware of how much time they spend in a sitting position and on physical activity [14]. It seems that the plan of the therapeutic treatment should include questionnaires with physical activity and sitting time. This method can be helpful in informing the patient about the risks of sedentary lifestyle. It would also allow to better monitor the progress of the therapy [15-17]. According to the American Diabetes Association, patients who suffer from metabolic syndrome, including NAFLD, should increase physical activity and adopt a well-balanced diet. Losing weight through exercise, physical activity, and caloric restriction associated with the proper diet are key elements in the struggle against dyslipidaemia and the prevention of cardiovascular disease. These actions help to reduce the LDL cholesterol fraction and blood triglycerides concentration, and increase HDL cholesterol [18-21].

Dietary intervention and a physical activity plan are important factors in the treatment of non-alcoholic fatty liver disease. Taking regular exercise increases insulin sensitivity and prevents further development of the disease. It seems that diet and physical activity are not the only risk factors of NAFLD. Our study reveals that reduction of sitting time has a positive effect on the level of insulin and the reduction of insulin resistance in patients with NAFLD.

\section{Acknowledgments}

Supported by a grant from the NCN: Nr N N404 150539.

\section{Conflict of interest}

The authors declare no conflict of interest.

\section{References}

1. Wilborn C, Beckham J, Campbell B, et al. Obesity: prevalence, theories, medical consequences, management, and research directions. J Int Soc Sports Nutr 2005; 2: 4-31.

2. Angulo P, Lindor K. Non-alcoholic fatty liver disease. J Gastroenterol Hepatol 2002; 17: 186-90.

3. Szostak WB, Cybulska B. Zespół metaboliczny. Nowy cel w profilaktyce chorób sercowo-naczyniowych. Lek Rodz 2004; 9: 792-803.

4. Zwolak A, Jastrzębska I, Tomaszewski M, et al. Rola wątroby w rozwoju insulinooporności. Post Nauk Med 2010; 1: 75-80.
5. Raszeja-Wyszomirska J, Ławniczak M, Marlicz W, et al. Niealkoholowa choroba stłuszczeniowa wątroby - nowe spojrzenie. Pol Merk Lek 2008; 24: 568-70.

6. Biernat E. Międzynarodowy kwestionariusz aktywności fizycznej - polska długa wersja. Medycyna Sportowa 2013; 29: 1-15.

7. Hamaguchi M, Kojima T, Itoh Y, et al. The severity of ultrasonographic findings in nonalcoholic fatty liver disease reflects the metabolic syndrome and visceral fat accumulation. Am J Gastroenterol 2007; 102: 2708-15.

8. Hagströmer M, Oja P, Sjöström M. The International Physical Activity Questionnaire (IPAQ): a study of concurrent and construct validity. Public Health Nutr 2006; 9: 755-62.

9. Uruska A, Araszkiewicz A. Insulinooporność w cukrzycy typu 1. Pediatr Endocrinol Diabetol Metabolism 2009; 15: 119-23.

10. Wesołowski P, Wańkowicz Z. Insulinooporność - metody rozpoznawania i następstwa kliniczne. Nefrol Dial Pol 2011; 15: 243-6.

11. Buchner DA, Charrier A, Srinivasan E, et al. Zinc finger protein 407 (ZFP407) regulates insulin-stimulated glucose uptake and glucose transporter 4 (Glut4) mRNA. J Biol Chem 2015; 290: 6376-86.

12. Bogdanski P, Pupek-Musialik D, Hen K, et al. Ocena wpływu 6-miesięcznej aktywności fizycznej na stopień insulinowrażliwości u otyłych kobiet z zespołem metabolicznym. Farm Współcz 2008; 1: 129-35.

13. Pilacinski S, Zozulinska-Ziolkiewicz DA. Influence of lifestyle on the course of type 1 diabetes mellitus. Arch Med Sci 2014; 10: $124-34$

14. Hallsworth K, Thoma C, Moore S, et al. Non-alcoholic fatty liver disease is associated with higher levels of objectively measured sedentary behaviour and lower levels of physical activity than matched healthy controls. Frontline Gastroenterol 2015; 6: 44-51.

15. Harrison SA, Day CP. Benefits of lifestyle modification in NAFLD. Gut 2007; 56: 1760-9.

16. Tarantino G, Finelli C. Have guidelines addressing physical activity been established in nonalcoholic fatty liver disease? World J Gastroenterol 2012; 18: 6790-800.

17. Zelber-Sagi S, Nitzan-Kaluski D, Goldsmith R. Role of leisure-time physical activity in nonalcoholic fatty liver disease: a population-based study. Hepatology 2008; 48: 1791-8.

18. Matuszak M, Suliburska J. Znaczenie redukcji masy ciała w leczeniu chorób metabolicznych. Forum Zaburzeń Metabolicznych 2012; 3: 104-9.

19. Kruszyńska A. Zespół metaboliczny: insulinooporność, hiperlipidemia i nadciśnienie tętnicze. Endokrynol Pol 2004; 4: 528-9.

20. Boudou P, de Kerviler E, Erlich D, et al. Exercise training-induced triglyceride lowering negatively correlates with DHEA levels in men with type 2 diabetes. Int J Obes Relat Metab Disord 2001; 25: 1108-12.

21. Paul D, Thompson, Buchner D. Exercise and physical activity in the prevention and treatment of atherosclerotic cardiovascular disease. Circulation 2003; 107: 3109-16.

Received: 20.02.2015

Accepted: 11.08.2015 